\title{
Lymphocyte and lymphocyte subset numbers in blood and in bronchoalveolar lavage and pleural fluid in various forms of human pulmonary tuberculosis at presentation and during recovery
}

\author{
G M Ainslie, J A Solomon, E D Bateman
}

\begin{abstract}
Background Lymphocytes have a central role in human defences against mycobacteria. A study was designed to assess the relation between lymphocyte responses and clinical pattern of disease, nutrition and recovery during treatment in patients with tuberculosis.
\end{abstract}

Methods Lymphocyte numbers and subsets (on the basis of CD3, CD4, and CD8 monoclonal antibodies) were measured in peripheral blood and, where appropriate, bronchoalveolar lavage or pleural fluid of patients with different forms of pulmonary tuberculosis. Eleven had localised pulmonary tuberculosis, 18 miliary tuberculosis and seven a tuberculous pleural effusion.

Results CD4 lymphocytes were found in greatly increased numbers in pleural fluid and were relatively depleted in the blood. Lymphocyte numbers in bronchoalveolar lavage fluid varied widely in localised pulmonary and miliary tuberculosis but were highest in lavage fluid from patients with miliary tuberculosis. This was due to an increase in CD8 lymphocytes, which were also increased in the blood. Lymphocyte numbers bore no relation to nutrition, symptom duration, or radiographic profusion scores. In miliary tuberculosis the time taken for the chest radiograph to clear (mean (SD) $17.6(7.8)$ weeks) correlated with lymphocyte numbers in lavage fluid, especially CD8 cells $(r=0.74)$, but not with the patients' age or nutrition. After 8 weeks' treatment, total and CD4 lymphocyte numbers in lavage fluid showed a substantial increase.

Conclusion The association of CD8 cells with delayed recovery is compatible with suppression of the antimycobacterial action of macrophages. The switch to predominance of $\mathrm{CD} 4$ cells in lavage fluid during successful treatment supports the view that they may have a role in eliminating mycobacteria.

The variable manifestations and natural history of pulmonary tuberculosis are determined by host factors, including cell mediated immunity, rather than differences in virulence of different strains of Mycobacterium tuberculosis. ${ }^{1}$ The immune response to $M$ tuberculosis involves subpopulations of specifically sensitised CD4 helper/inducer or cytolytic T lymphocytes. ${ }^{1-5}$ Most reports of human disease are based on findings in blood and pleural fluid..$^{5-10}$ In advanced or disseminated tuberculosis circulating $\mathrm{T}$ cells, especially CD4 cells, are reduced in number and CD8 $\mathrm{T}$ cells are increased relatively. ${ }^{581011}$ In tuberculous pleural effusions CD4 functionally helper T cells are increased in the pleural fluid compared with blood. ${ }^{61213}$ There have been few reports of lymphocytes in infected lungs. Options for studying these include examination of pathology specimens and cells recovered by bronchoalveolar lavage. Previous studies of lymphocytes in lavage fluid in tuberculosis have shown increased numbers of lymphocytes in local $^{14}$ and miliary tuberculosis. ${ }^{15}$

We have compared lymphocyte numbers and subsets in the lungs, blood and, where possible, the pleura of patients with different forms of pulmonary tuberculosis (local, miliary and pleural) and assessed the serial changes that occurred during successful treatment.

\section{Methods}

STUDY POPULATION

Approval for the study was obtained from the Medical Faculty Research and Ethics Committee. All patients gave informed written consent for participation in the study. The study groups comprised seven patients with tuberculosis pleurisy, 11 with localised pulmonary tuberculosis (tuberculosis confined to one lobe or segment) and 18 with miliary tuberculosis. All patients were black or of mixed race. In each case direct sputum examination failed to show acid and alcohol fast bacilli and bronchoscopy and/or thoracocentesis were required to confirm active tuberculosis. The clinical assessment included measurement of body mass, height, triceps skinfold thickness, ${ }^{16}$ midarm circumference, ${ }^{16}$ and serum albumin; chest radiography; a full blood count; and a Mantoux skin test employing $5 \mathrm{TU}$ purified protein derivative (PPD). Chest radiographs were reviewed and the size, profusion and distribution of lung changes assessed according to the UICC/ILO standard radiographs for 
pneumoconiosis. ${ }^{17}$ A composite profusion score combining these three features (with a maximal possible score of 18 points) was calculated for each plate. Human immunodeficiency virus status was not tested as there were no cases of AIDS (other than in white homosexuals) in the Cape Town region during the study period (1982-86), and retrospective populationwide serum testing identified only 20 positive cases in persons of mixed race, and none in blacks. No patients received corticosteroid treatment.

\section{COLLECTION OF LYMPHOCYTES}

Lymphocytes were obtained before or within 3 days of commencement of antituberculosis drugs from peripheral blood in all patients, from bronchoalveolar lavage fluid in patients with localised pulmonary or miliary tuberculosis and from pleural fluid in patients with a pleural effusion. Bronchoalveolar lavage was performed during fibreoptic bronchoscopy under topical anaesthesia with $4 \%$ lignocaine, following premedication with $0.6 \mathrm{mg}$ atropine and 5-10 mg diazepam intravenously. Sterile $0.9 \%$ saline was instilled in $20 \mathrm{ml}$ aliquots to a total of $220 \mathrm{ml}$. The first aliquot was presumed to be bronchially contaminated and was discarded. In miliary tuberculosis the lavage was performed in a lateral subsegment of the right middle lobe or the lingula. In localised pulmonary tuberculosis an affected (usually upper) and an unaffected lobe (usually the middle or lingula) were lavaged separately. Bronchial brushings and transbronchial lung biopsy specimens were also obtained for diagnostic purposes. The percentage yield of lavage fluid ranged from $50 \%$ to $84 \%$. There was no significant difference in the yields from the three groups (mean yield in miliary tuberculosis $64 \%$, localised pulmonary tuberculosis, affected lobe $58 \%$ and unaffected lobe $61 \%$ ). Pleural fluid, obtained by thoracocentesis, was heparinised and subjected to cytological and bacteriological examination. Pleural biopsy samples obtained with an Abram's needle were examined histologically and cultured. Peripheral blood was obtained by venepuncture immediately after bronchoscopy or thoracocentesis and heparinised.

\section{PREPARATION AND ANALYSIS OF CELLS}

Lavage and pleural fluid were kept on ice, strained through gauze, spun down and the resultant cell pellet washed three times with RPMI-1640 and resuspended in RPMI containing $10 \%$ fetal calf serum. Total cell counts were performed in a haemocytometer and differential counts from May-Grünewald-Giemsa stained cytocentrifuge preparations of $10^{5}$ cells. Mononuclear cell preparations were made from lavage fluid, pleural fluid or peripheral blood by Ficoll-Hypaque centrifugation, ${ }^{18}$ and lymphocytes separated from monocytes/ macrophages by adherence on to plastic petri dishes for 1-2 hours followed by passage through nylon wool columns. ${ }^{19}$ Identification of $\mathrm{T}$ lymphocyte subsets was performed with OKT murine monoclonal human $T$ cell antibodies (Ortho Pharmaceuticals, Raritan,
New Jersey, USA) where OKT3 (CD3) stains for all mature T cells, OKT4 (CD4) for helper/ inducer and OKT8 (CD8) for suppressor/ cytotoxic subsets. A volume of $5 \mu \mathrm{l}$ of each of OKT3, OKT4 and OKT8 antibodies was added to $200 \mu \mathrm{l}$ aliquots of a $2-5 \times 10^{6} \mathrm{ml}$ preparation of lymphocytes at $4{ }^{\circ} \mathrm{C}$ for 30 minutes. Following two washes with medium, the cells were stained with $100 \mu \mathrm{l}$ of a $40 x$ dilution of fluorescein conjugated goat anti mouse immunoglobulin (Cappel Laboratories, Cochranville, Pennsylvania, USA) for $20 \mathrm{~min}$ utes at $4{ }^{\circ} \mathrm{C}$, then washed three times and counted in a fluorescence activated cell sorter (Coulter model TPS-1, Coulter Electronics Inc, Hialeah, Florida, USA). An identical aliquot of cells, treated in the same way but without OKT antibody, served as control. Channel by channel subtraction of control fluorescence from test specimen counts was performed by a specially prepared computer program. Studies of T cell subsets were performed on peripheral blood and pleural fluid from all patients with pleural tuberculosis but, for logistical reasons, on blood and lavage fluid from only eight patients with localised pulmonary tuberculosis and 12 patients with miliary disease.

\section{ASSESSMENT DURING RECOVERY}

Clinical assessment was repeated at monthly intervals for 6 months after initiation of antituberculous treatment. Studies of lavage $T$ cell numbers and subsets were repeated on five patients with miliary tuberculosis after eight weeks of antituberculous treatment once radiographic clearing had begun. Repeat studies of blood $T$ cell numbers and subsets were performed at four, eight, and twelve weeks on these five subjects, and in a further five patients with miliary tuberculosis, five with localised pulmonary tuberculosis and five with pleural disease. These subgroups were similar to and representative of the original groups.

\section{NORMAL VALUES}

Normal values for lavage results were obtained from seven normal control subjects and those for $T$ cell subsets in peripheral blood from 12 normal control subjects with a mean age of $33.4(8.9)$ years. Seven were males, five $(42 \%)$ were smokers, ten were of mixed race and two were black. There was no significant difference between the controls and patients with respect to any of the above. The normal values quoted for other tests are those validated and accepted in our hospital and medical school laboratory.

\section{ANALÝSIS}

All data unless stated to the contrary are presented as mean (SD). Statistical comparisons are made with the two-tailed Student's $t$ test, Wilcoxon sign test or Mann-Whitney U test.

\section{Results}

STUDY POPULATION AND NUTRITION (table 1)

There were more females in the group with miliary tuberculosis than in the other two groups, but ages, numbers of smokers and 
Table 1 Mean (SD) demographic and nutritional data at presentation of patients with pulmonary and pleural tuberculosis

\begin{tabular}{lccc}
\hline & $\begin{array}{l}\text { Pleural } \\
\text { tuberculosis } \\
(n=7)\end{array}$ & $\begin{array}{l}\text { Local } \\
\text { tuberculosis } \\
(n=11)\end{array}$ & $\begin{array}{l}\text { Miliary } \\
\text { tuberculosis } \\
(n=18)\end{array}$ \\
\hline Age (years) & $31 \cdot 9(15 \cdot 1)$ & $37 \cdot 4(17 \cdot 9)$ & $36 \cdot 2(17 \cdot 5)$ \\
Sex $(M:$ F) & $6: 1$ & $7: 4$ & $7: 11$ \\
Smokers & 3 & 8 & 10 \\
Duration of symptoms (weeks) & $1 \cdot 9(2 \cdot 2)$ & $2 \cdot 8(3 \cdot 4)$ & $2 \cdot 2(2 \cdot 03)$ \\
Body mass (\% ideal) $\dagger$ & $91 \cdot 7(22 \cdot 6)$ & $96 \cdot 3(8 \cdot 8)$ & $95 \cdot 1(17 \cdot 8)$ \\
Midarm circumference & $19 \cdot 5(27 \cdot 9)$ & $22 \cdot 8(22 \cdot 2)$ & $15 \cdot 1(21 \cdot 5)$ \\
$\quad$ (\% of predicted) $\ddagger$ & $31(18 \cdot 8)$ & $24(26 \cdot 2)$ & $16 \cdot 8(26 \cdot 2)$ \\
$\quad$ Triceps skinfold thickness & $36 \cdot 7(5 \cdot 9)$ & $37 \cdot 7(6 \cdot 1)$ & $30 \cdot 3(4 \cdot 8)^{\star}$ \\
Serum albumin $(\mathrm{g} / 1) \S$ & 5 & 11 & 8 \\
Positive Mantoux reactivity & & & \\
\hline
\end{tabular}

${ }^{\star} p$ values (Mann-Whitney $U$ test) versus local tuberculosis, $p<0.05$. $\dagger 1969$ Metropolitan Life Insurance Co standards. †Frisancho, $1974 .{ }^{16} §$ Normal values: albumin $35-50 \mathrm{~g} / \mathrm{l}$. duration of symptoms were similar. Four patients with miliary tuberculosis and two each with localised pulmonary disease and tuberculous pleural effusions had a regular heavy intake of alcohol. Body mass was above the 90th centile in all groups but midarm circumference and triceps skin fold thickness were markedly reduced (below 24th centile). Serum albumin was significantly reduced in patients with miliary tuberculosis compared with those with localised pulmonary tuberculosis. More patients with miliary disease displayed anergy to PPD.

CELL COUNTS IN BLOOD AND LAVAGE AND PLEURAL FLUID (table 2)

Peripheral blood lymphopenia (less than $1.5 \times$ $\left.10^{9} / 1\right)$ was present in six of seven patients with pleural disease, nine of 18 with miliary disease and seven of 11 with localised pulmonary tuberculosis. In the groups as a whole blood lymphocyte numbers were only reduced significantly in those with pleural disease $\left(1.06(0.46) \times 10^{9} / 1, \mathrm{p}<0.05\right)$. The total cell count and lymphocyte yield in lavage fluid, whether expressed as total lymphocytes, percentage of lymphocytes or lymphocytes $/ \mathrm{ml}$ lavage fluid, were significantly increased in miliary tuberculosis. Lymphocyte numbers expressed per $\mathrm{ml}$ lavage fluid were elevated in both affected and unaffected lobes in localised pulmonary tuberculosis with a trend towards more lymphocytes in the affected than the unaffected lobe. A modest increase in the percentage of neutrophils was seen in the affected lobe of localised pulmonary tuberculosis but the proportion of eosinophils was normal in all categories of disease. More than $90 \%$ of cells in pleural fluid were lymphocytes (lymphocyte number $\left.1234(1196) \times 10^{3} / \mathrm{ml}\right)$.

Lymphocyte numbers in lavage fluid of patients with miliary tuberculosis bore a weak positive relationship to patient's age $(r=$ $0.544 ; p<0.05$ ) but were unrelated to alcohol intake, duration of symptoms, chest radiographic profusion, measures of nutrition, serum albumin or peripheral blood lymphocyte numbers.

T LYMPHOCYTE SUBSETS (figure 1)

Peripheral blood CD3 cells ( $\mathrm{T}$ lymphocytes) were present in similar proportions in control and disease categories (mean (SD) percentages of CD3 lymphocytes in peripheral blood were $68.6(10.6)$ in localised pulmonary tuberculosis, $73(9 \cdot 1)$ in miliary tuberculosis and 71.8 (11) in pleural tuberculosis versus 68.4 (9.8) in control subjects). The ratio of CD4 to CD8 cells, however, was significantly lower in peripheral blood from patients (mean (SD) of CD4 : 8 was $1.6(0.58)$ in miliary disease, 1.76 $(0 \cdot 88)$ in localised pulmonary tuberculosis and $1.21(0.43)$ in pleural disease) than in blood from normal subjects $(2 \cdot 2(0.8), p<0.05)$. A similar but more pronounced trend was present in lavage fluid, especially in miliary disease (mean (SD) of CD4 : 8 lymphocytes in lavage fluid was $0.86(0.43)$ in miliary tuberculosis, $1.23(0.28)$ in localised pulmonary tuberculosis affected lobe, and $1.02(0.23)$ in the unaffected lobe versus $1.98(0.36)$ in normal subjects, $p<$ $0 \cdot 01)$. The low CD4 : 8 ratio in blood was due to an absolute decrease of CD4 cells (means of absolute numbers of CD4/CD8 lymphocytes $\times 10^{6}$ in blood: $629 / 451$ in miliary tuberculosis, $692 / 454$ in localised pulmonary tuberculosis and $406 / 355$ in tuberculous effusions versus $771 / 453$ in control subjects). In the lavage fluid

Table 2 Mean (SD) numbers and proportions of cells in peripheral blood and bronchoalveolar lavage fluid

\begin{tabular}{|c|c|c|c|c|c|c|c|c|c|c|}
\hline & \multirow{3}{*}{$\begin{array}{l}\text { Peripheral } \\
\text { blood } \\
\text { lymphocytes } \\
\left(\times 10^{9} / l\right)\end{array}$} & \multicolumn{9}{|c|}{ Bronchoalveolar lavage fluid } \\
\hline & & \multirow[b]{2}{*}{$\begin{array}{l}\text { Total } \\
\text { cell yield } \\
\left(\times 10^{\circ}\right)\end{array}$} & \multirow[b]{2}{*}{$\begin{array}{l}\text { Lympho- } \\
\text { cytes } \\
(\%)\end{array}$} & \multirow{2}{*}{$\begin{array}{l}\text { Total } \\
\text { lympho- } \\
\text { cytes } \\
\left(\times 10^{3}\right)\end{array}$} & \multirow[b]{2}{*}{$\begin{array}{l}\text { Lympho- } \\
\text { cytes } \\
\left(\times 10^{3} / \mathrm{ml}\right)\end{array}$} & \multirow[b]{2}{*}{$\begin{array}{l}\text { Neutrophils } \\
(\%)\end{array}$} & \multirow[b]{2}{*}{$\begin{array}{l}\text { Eosinophils } \\
(\%)\end{array}$} & \multicolumn{3}{|c|}{ Macrophages } \\
\hline & & & & & & & & $\begin{array}{l}\text { Inorganic } \\
\text { inclusions } \\
(\%)\end{array}$ & $\begin{array}{l}\text { Clear } \\
\text { foamy } \\
(\%)\end{array}$ & $\begin{array}{l}\text { Giant } \\
\text { cells } \\
(\%)\end{array}$ \\
\hline $\begin{array}{l}\text { Control } \\
(n=8) \\
\text { Local tuberculosis } \\
\text { affected lobe } \\
(\mathrm{n}=11)\end{array}$ & $\begin{array}{l}1.79 \\
(0.57) \\
1.67 \\
(0.66)\end{array}$ & $\begin{array}{l}10 \cdot 9 \\
(5 \cdot 4) \\
20 \cdot 6 \\
(13 \cdot 4)\end{array}$ & $\begin{array}{l}5 \cdot 4 \\
(3 \cdot 6) \\
14 \cdot 2 \\
(12 \cdot 2)\end{array}$ & $\begin{array}{l}601 \\
(469) \\
2118 \dagger \\
(1891)\end{array}$ & $\begin{array}{l}5 \cdot 4 \\
(2 \cdot 7) \\
41 \cdot 5 \dagger \\
(61 \cdot 7)\end{array}$ & $\begin{array}{l}2 \cdot 3 \\
(1 \cdot 7) \\
5 \cdot 3 \dagger \\
(4 \cdot 5)\end{array}$ & $\begin{array}{l}0 \cdot 6 \\
(0 \cdot 6) \\
2 \cdot 3 \\
(2 \cdot 9)\end{array}$ & $\begin{array}{l}29 \cdot 0 \\
(28 \cdot 7) \\
34 \cdot 4 \\
(26 \cdot 9)\end{array}$ & $\begin{array}{l}55 \cdot 4 \\
(27 \cdot 5) \\
39 \cdot 7 \\
(22 \cdot 2)\end{array}$ & $\begin{array}{l}7 \cdot 4 \\
(3 \cdot 8) \\
5 \cdot 2 \\
(3 \cdot 3)\end{array}$ \\
\hline $\begin{array}{l}\text { Local tuberculosis } \\
\text { unaffected lobe } \\
(\mathrm{n}=7)\end{array}$ & & $\begin{array}{l}19.9 \\
(12.9)\end{array}$ & $\begin{array}{c}7 \cdot 1 \\
(5 \cdot 0)\end{array}$ & $\begin{array}{l}1633 \dagger \\
(730)\end{array}$ & $\begin{array}{l}13 \cdot 4 \dagger \\
(6 \cdot 4)\end{array}$ & $\begin{array}{l}0 \cdot 8 \\
(0 \cdot 8)\end{array}$ & $\begin{array}{l}0.9 \\
(1 \cdot 1)\end{array}$ & $\begin{array}{l}35 \cdot 8 \\
(17 \cdot 7)\end{array}$ & $\begin{array}{l}49 \cdot 8 \\
(14 \cdot 2)\end{array}$ & $\begin{array}{l}6 \cdot 5 \\
(1 \cdot 2)\end{array}$ \\
\hline $\begin{array}{l}\text { Miliary tuberculosis } \\
\quad(\mathrm{n}=18)\end{array}$ & $\begin{array}{l}1 \cdot 48 \\
(0 \cdot 76)\end{array}$ & $\begin{array}{l}33.3 \dagger \\
(20.9)\end{array}$ & $\begin{array}{l}19 \cdot 1^{\star} \\
(15 \cdot 4)\end{array}$ & $\begin{array}{l}6916^{\star} \\
(7795)\end{array}$ & $\begin{array}{l}58.9 \dagger \\
(69)\end{array}$ & $\begin{array}{l}2 \cdot 3 \\
(1 \cdot 7)\end{array}$ & $\begin{array}{l}0 \cdot 3 \\
(0 \cdot 5)\end{array}$ & $\begin{array}{l}34 \cdot 5 \\
(25 \cdot 1)\end{array}$ & $\begin{array}{l}32 \cdot 7^{\star} \\
(21 \cdot 1)\end{array}$ & $\begin{array}{l}8 \cdot 8 \\
(6 \cdot 8)\end{array}$ \\
\hline
\end{tabular}

$\mathrm{p}$ values (versus controls): ${ }^{\star} \mathrm{p}<0.05,+\mathrm{p}<0.01$. 
Tlymphocyte OKT4:8 (CD4:8) ratios in peripheral blood, bronchoalveolar lavage fluid and pleural fluid in patients with different forms of pulmonary tuberculosis. Bar values represent mean (standard deviation).

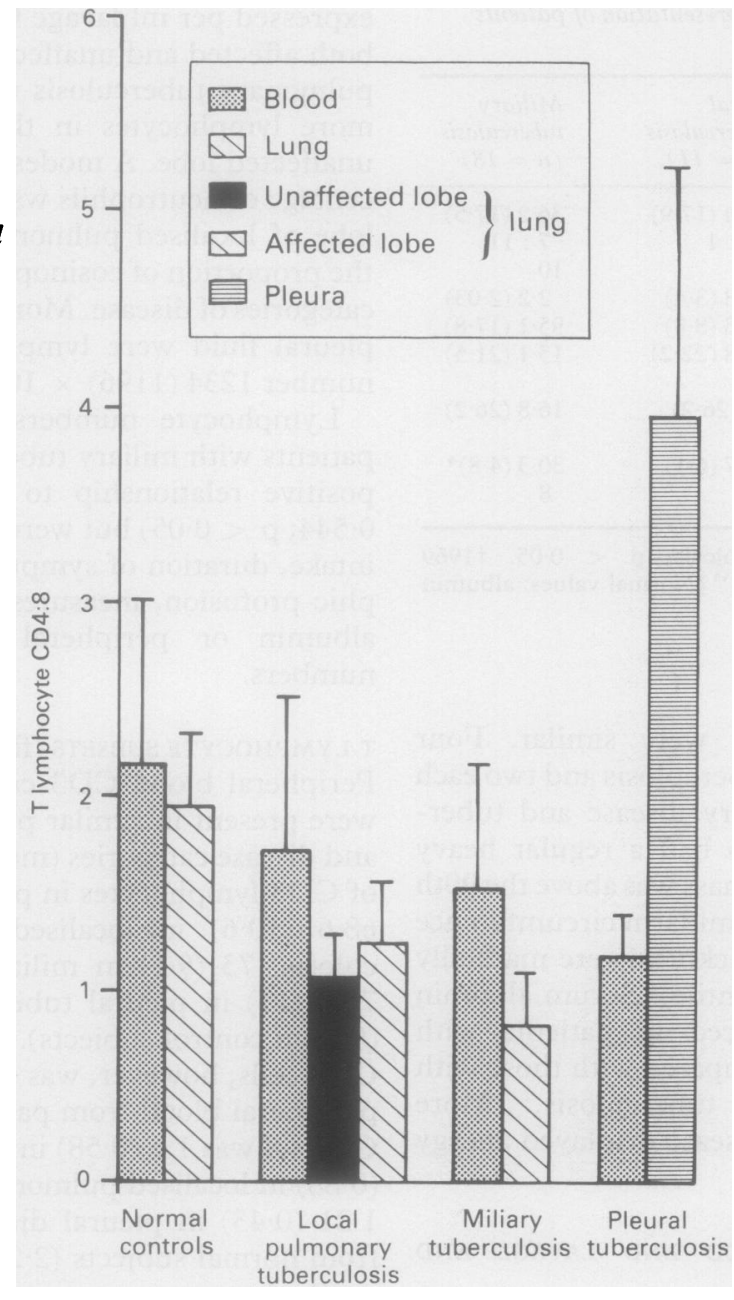

the low CD4: 8 ratios were due to a greater increase in CD8 than CD4 lymphocytes (means of absolute numbers of $\mathrm{CD} 4 / \mathrm{CD} 8$ lymphocytes $\times 10^{3}$ in lavage fluid: $1916 / 2469$ in miliary tuberculosis and 534/446 in localised pulmonary tuberculosis versus $235 / 138$ in normal subjects). In the pleural fluid the majority of cells were CD4 T lymphocytes. The CD4 : 8 ratio was high in pleural fluid (3.92 (1.3) ) and low in blood $(1 \cdot 21(0 \cdot 43))$.

\section{LYMPHOCYTE NUMBERS AND SUBSETS DURING} RECOVERY

Total lymphocyte numbers in peripheral blood in miliary tuberculosis did not change significantly during the first 12 weeks of treatment, remaining in the low normal range, although the proportion of CD4 cells increased (table 3). By contrast, in localised pulmonary tuberculosis and pleural disease, lymphocyte numbers increased from $1 \cdot 14(0.44)$ to $1.66(0.61) \times$ $10^{9} / 1(\mathrm{p}<0.01)$ in the first four weeks, without a significant change in subsets.

The proportion and absolute numbers of lymphocytes in bronchoalveolar lavage rose strikingly by eight weeks owing to an increase in CD4 cells.

\section{RADIOGRAPHIC RESOLUTION}

Radiographic resolution occurred most rapidly in patients with tuberculous pleural effusions (by 8.7 (6) weeks) and was similar for localised pulmonary $(17.8(5 \cdot 8)$ weeks) and miliary tuberculosis $(17 \cdot 6(7 \cdot 8)$ weeks). In patients with miliary tuberculosis there was a significant linear correlation between radiographic recovery time and total lymphocyte numbers $(\mathrm{r}=0.55 ; \mathrm{p}<0.05)$, percentage of lymphocytes $(r=0.66 ; p<0.01)$ and, most notably, the CD8 lymphocyte number $(r=$ $0.74 ; \mathrm{p}<0.01)$ in lavage fluid. The higher the initial CD8 lymphocyte numbers in lavage fluid, the longer it took for the chest radiograph to improve.

\section{Discussion}

An increased number of lymphocytes is a feature of the histopathology of pulmonary tuberculosis, and was therefore an expected finding in the bronchoalveolar lavage fluid of such patients. Contrary to expectations, however, they were elevated in only $55 \%$ of patients with local pulmonary tuberculosis and in $60 \%$ of those with miliary disease. The variable yield of lymphocytes probably reflects the individual variation in inflammatory response to mycobacterial infection. A second observation was that there was a greater increase in CD8 $\mathrm{T}$ lymphocytes than in the CD4 lymphocytes usually considered central to antimycobacterial defences. ${ }^{1-5}$ This change was also in the peripheral blood in radiologically normal lobes in patients with non-cavitatory localised disease. Differences in the lung lymphocyte subpopulation in different clinical forms of tuberculosis were quantitative only.

Table 3 Mean (SD) changes in lymphocyte numbers and T lymphocyte subsets during treatment of miliary tuberculosis

\begin{tabular}{|c|c|c|c|c|}
\hline & \multirow[b]{2}{*}{ Before treatment } & \multicolumn{3}{|c|}{ Weeks of treatment } \\
\hline & & 4 weeks & 8 weeks & 12 weeks \\
\hline $\begin{array}{l}\text { Peripheral blood }(\mathrm{n}=10) \\
\text { Lymphocytes }\left(\times 10^{9} / 1\right) \\
\text { CD4 }(\% \text { of T cells }) \\
\text { CD4 : CD8 }\end{array}$ & $\begin{array}{c}1.56(0.27) \\
57.8(4 \cdot 7) \\
1.59(0.26)\end{array}$ & $\begin{array}{c}1.33(0.22) \\
61.8(4.7) \\
2.08(0.45)\end{array}$ & $\begin{array}{c}1.38(0.23) \\
62 \cdot 1(4.2) \\
1.91(0.43)\end{array}$ & $\begin{array}{c}1.63(0.41) \\
63 \cdot 6(8.3)^{\star} \\
2.54(0.83)^{\star}\end{array}$ \\
\hline $\begin{array}{l}\text { Bronchoalveolar lavage }(\mathrm{n} \\
\text { Lymphocytes }(\%) \\
\text { Lymphocytes }\left(\times 10^{6}\right) \\
\text { CD4 }(\% \text { of T cells) } \\
\text { CD4 : CD8 }\end{array}$ & $\begin{array}{l}23.6(8.8) \\
41 \cdot 3(20 \cdot 5) \\
47.9(4 \cdot 7) \\
0.99(0 \cdot 19)\end{array}$ & & $\begin{array}{c}40 \cdot 0(9 \cdot 9)^{\star} \\
75 \cdot 2(25 \cdot 8)^{\star} \\
72 \cdot 3(1 \cdot 6) \dagger \\
2 \cdot 66(0 \cdot 2) \dagger\end{array}$ & \\
\hline
\end{tabular}

$p$ values versus before treatment: ${ }^{\star} p<0.05 ; \uparrow p<0.01$ 
The changes in pleural tuberculosis, namely mild peripheral blood lymphopenia and a low CD4 : 8 ratio, in association with a marked pleural lymphocytosis, have been described previously..$^{5-7}$ An interesting finding in the current study is the differing responses in the pleura and lung. In one patient with both miliary tuberculosis and a pleural effusion, the pleural fluid lymphocyte CD4 : 8 ratio was $4 \cdot 3$ (representing the expected excess of CD4 cells) while a marked CD8 lymphocyte excess (CD4 : $8=1 \cdot 1$ ) was noted in the lavage fluid. The reason for this difference in $T$ cell subsets in the different compartments is not clear. It is possible that there are differences in the accessory cell function of pleural macrophages ${ }^{20}$ or that a brief and spontaneously remitting CD8 phase occurs during the early stage of pleural infection, before the CD4 cell proliferation that is associated with marked pleural exudates, and in the lung in miliary disease during successful treatment.

It is relevant to ask what factors determine the intensity of lymphocyte response in local and miliary tuberculosis. In the latter, no relationship with profusion of chest radiographic abnormality, duration of symptoms and measures of nutrition was observed. Dhand et $a l^{15}$ have shown a relative increase in total cell and lymphocyte counts in poorly nourished patients with local disease, especially when extensive. Increased $T$ suppressor cells and a lower $\mathrm{T}$ helper to suppressor ratio have been observed in malnutrition ${ }^{21} 22$ and with advanced age. ${ }^{23}$ This shift, however, is usually associated with reduced $\mathrm{T}$ lymphocyte numbers. A heavier load of infecting organisms is an alternative explanation and, as this was not measured in our study, remains a possibility. A switch to functionally suppressive $T$ cell proliferation with increased dose of mycobacteria has been observed in experimental animals, but total cell numbers did not increase greatly. ${ }^{24}$

Previous studies looking at the pattern of lymphocyte responses during treatment have been confined to peripheral blood. Our patients with sputum negative localised pulmonary and pleural disease showed a lymphopenia at presentation, which resolved on treatment, as was seen with Onwubalili and Scott with sputum positive localised pulmonary tuberculosis. ${ }^{25}$ The CD4 : 8 ratio did not rise significantly in our patients, unlike the sputum positive and sputum negative patients of Singhal et al. ${ }^{11}$ Our patients with miliary tuberculosis showed a rise in the blood CD4 : 8 ratio during treatment, as did the patients of Bhatnagar et al. ${ }^{8}$ Their lymphopenia, however, did not resolve within the first 12 weeks.

This is the first study to assess the changes in cellular response in the lungs of patients with miliary tuberculosis during treatment, and to relate them to radiographic resolution. There was an inverse relationship between rate of recovery of miliary tuberculosis and total lymphocyte numbers and CD8 cells in lavage fluid at presentation. The differing rates of recovery were not accounted for by different profusion of abnormality on chest radiography or the patients' nutrition. It is not clear whether the increased CD8 cells form an essential part of the delayed recovery or whether they merely reflect more severe infection.

It is important to establish the functional role of the CD8 cells observed in our study. Effective host defence against mycobacteria involves collaboration between mononuclear phagocytes and lymphocytes, the final pathway being inhibition of mycobacterial replication within macrophages. ${ }^{26}$ Lymphokines from specifically sensitised clones of CD4 helper lymphocytes have been thought to be central to this process. $^{327}$ The CD4 lymphocyte response is potentially tissue damaging as lymphokines are produced which prime macrophages for massive release of tumour necrosis factor when mycobacteria are ingested. ${ }^{28}$ If the CD8 cells shown in this study have suppressor function, they may serve to downregulate the proliferation of CD4 cells and potentially damaging host responses. This might be done at the expense of delaying clearance of the organism. Functionally suppressive lymphocytes have been identified in human tuberculous infections ${ }^{29} 30$ and experimental models. ${ }^{3132}$ As yet there is no evidence for CD8 cytotoxic $\mathrm{T}$ cells in human tuberculosis. ${ }^{33} 34$

There was a substantial increase in lymphocyte numbers in lavage fluid after eight weeks of treatment despite an improvement in the chest radiographs. This increasing lymphocytosis was associated with an impressive switch from CD8 to CD4 dominance. It is not clear what factors determine this change. It might follow as a consequence of diminishing bacterial load following antimycobacterial drug treatment. These observations in human pulmonary tuberculosis provide support for in vitro data emphasising the central role of $\mathrm{CD} 4$ cells in enhancing antimycobacterial responses mediated by macrophages. ${ }^{252735}$ The CD4 lymphocytes found in tuberculous pleural effusions have previously been shown to have helper function. ${ }^{5-736}$ Further studies of the functional characteristics of both early CD8 and later CD4 cells in human pulmonary tuberculosis, particularly those associated with high intensity lung lymphocyte responses, are necessary.

In summary, we have established that the intensity of the lymphocyte responses in lung infected with $M$ tuberculosis varies widely in individual patients.

The authors wish to thank Professor Eugene Dowdle of the Department of Clinical Science and Immunology for advice and use of laboratory facilities, Sister Cecelia Wilson for her excellent assistance during bronchoscopies and Mrs A Singer for typing this manuscript. Financial support from the South African Medical Research Council and Guy Elliot Postgraduate Research Fellowship of the University of Cape Town is gratefully acknowledged.

1 Collins FM. The immunology of tuberculosis. Am Rev Respir Dis 1982;125:42-9.

2 Edwards D, Kirkpatrick CH. The immunology of mycobacterial diseases. Am Rev Respir Dis 1986;134:1062-71.

3 Matthews R, Scoging A, Rees ADM. Mycobacterial antigen-specific human $T$ cell clones secreting macrophage antigen-specifichuman T cell clones secreting mact

4 Ottenhoff TH, Ab BK, van Embden JD, Thole JE, Kiessling $\mathrm{R}$. The recombinant $65-\mathrm{kD}$ heat shock protein of Mycobacterium bovis Bacillus Calmette-Guerrin/M tuber- 
culosis is target molecule for CD4 + cytotoxic T lymphocytes that lyse human monocytes. J Exp Med 1988; 168:1947-52.

5 Shiratsuchi H, Tsuyaguchi I. Analysis of T cell subsets by monoclonal antibodies in patients with tuberculosis after in vitro stimulation with purified protein derivative of tuberculin. Clin Exp Immunol 1984;57:271-8.

6 Simon MR, Desai SG, Jennings J, Engel D. T cell differentiation antigens and antigenic lymphocyte reactivity in pleural effusions. Asian Pac J Allergy Immunol 1986;4: pleural

7 Shimokata K, Kishimoto H, Takagi E, Tsunekawa $\mathrm{H}$. Determination of the $\mathrm{T}$ cell subset producing gamma interferon in tuberculous pleural effusion. Microbio Immunol 1986;30:353-61.

8 Bhatnagar R, Malaviya A, Narayanan S, Rajgopalan P, Kumar R, Bharadwaj OP. Spectrum of immune response abnormalities in different clinical forms of tuberculosis. Am Rev Respir Dis 1977;115:207-12.

9 Ellner JJ. Pleural fluid and peripheral blood lymphocyte function in tuberculosis. Ann Intern Med 1978;89:932-3.

10 Swanson Beck J, Potts RC, Kardjito T, Grange JM. T4 lymphopenia in patients with active pulmonary tuberculosis. Clin Exp Immunol 1985;60:49-54.

11 Singhal M, Banavalikar JN, Sharma S, Saha K. Periphera blood $\mathrm{T}$ lymphocyte subpopulations in patients with tuberculosis and the effect of chemotherapy. Tubercle 1989;70:171-8.

12 Shimokata $\mathrm{K}$, Kawachi $\mathrm{H}$, Kishimoto $\mathrm{H}$, Maeda F, Ito $\mathrm{Y}$. Local cellular immunity in tuberculous pleurisy. Am Rev Respir Dis 1982;126:822-4.

13 Fujiwara H, Okuda Y, Fukukawa T, Tsuyuguchi I. In vitro tuberculin reactivity of lymphocytes from patients with tuberculous pleurisy. Infect Immunity 1982;35:402-9.

14 Sharma SK, Pan JN, Verma K. Bronchoalveolar lavage (BAL) in miliary tuberculosis. Tubercle 1988;69:175-8.

15 Dhand R, De A, Ganguly NK, Gupta N, Jaswal S, Malik SK, Kohli KK. Factors influencing the cellular response in bronchoalveolar lavage and peripheral blood of patients with pulmonary tuberculosis. Tubercle 1988;69:161-73.

16 Frisancho AR. Triceps skin fold and upper arm muscle size norms for assessment of nutritional status. Am J Clin Nutr 1974;27:1052-8.

17 International Labor Office. Guidelines for the use of the ILO International Classification of Radiography of Pneumoconiosis. Geneva: ILO, 1980 (Occupational Safety and Health Series No.80)

18 Boyum A. Isolation of mononuclear cells and granulocytes from human blood. Scand J Clin Lab Invest 1968; 21(Suppl 97):77-89.

19 Greaves MF, Brown S. Purification of human $T$ and $B$ lymphocytes. J Immunol 1974;112:420-3.

20 Tweardy DJ, Schacter BZ, Ellner JJ. Association of altered dynamics of monocyte surface expression of human leukocyte antigen DR with immunosuppression in tuberculosis. J Infect Dis 1984;149:31-7.
21 Keusch GT, Wilson CS, Waksal SD. Nutrition, host defenses, and the lymphoid system. In: Gallin JI, Fauci AS, eds. Advances in host defense mechanisms, Vol. 2. New York: Raven, 1983:275-359.

22 Chandra RK. Lymphocyte subpopulations in human malnutrition: cytotoxic and suppressor cells. Pediatrics 1977;59:423-9.

23 Chandra RK, Joshi I, Au B, Woodford G, Chandra S Nutrition and immunocompetence of the elderly. Effect of short term nutritional supplementation on cell-mediated immunity and lymphocyte subsets. Nutr Res 1982;2: 223-32.

24 Rook GAW. The immunological consequences of antigen overload in experimental mycobacterial infections in mice. Clin Exp Immunol 1975;19:167-78.

25 Onwubalili JK, Scott GM. Immune status in tuberculosis and response to treatment. Tubercle 1988;69:81-94.

26 Rook GAW, Champion BR, Steel J, Varey AM, Stanford $\mathrm{JL}$. I-A restricted activation by $\mathrm{T}$ cell lines of antituberculosis activity in murine macrophages. Clin Exp Immunol 1985;59:414-20.

27 Bach MA, Pennec JM, Flageul B, Wallach D, Cottenot F Specificity study of PPD-reactive human $\mathrm{T}$ cell lines and clones. Immunology Letters 1985;9:81-5.

28 Rook GAW, Taverne J, Leveton C, Steele J. The role of gamma-interferon, vitamin D3 metabolites and tumour necrosis factor in the pathogenesis of tuberculosis. Immunology 1987;62:229-34.

29 Tsuyuguchi I, Shiratsuchi $H$ Teraoka $O$, Hirano $T$ Increase in $T$ cells bearing IgG Fc receptors in peripheral blood of patients with tuberculosis by in vitro stimulation with purified protein derivative. Am Rev Respir Dis 1980;121:951-7.

30 Katz P, Goldstein RA, Fauci AS. Immunoregulation in infection caused by Mycobacterium tuberculosis: the presence of suppressor monocytes and alteration of subpopulations of $T$ lymphocytes. J Infect Dis 1979;140: populatior

31 Wadee AA, Sher R, Rabson AR. Production of a suppressor factor by human adherent cells treated with mycobacteria. J Immunol 1980;125:1380-6.

32 Mustafa AS, Godal T. BCG-induced suppressor T cells: optimal conditions for in vitro induction and mode of action. Clin Exp Immunol 1985;62:474-81.

33 Kaufman SHE. CD8 $+\mathrm{T}$ lymphocytes in intracellular microbial infections. Immunology Today 1988;9:168-74.

34 Rees A, Scoging A, Mehlert A, Young DB, Ivanyi J. Specificity of proliferative response of human CD8 clones to mycobacterial antigens. Eur J Immunol 1988;18:1881-7.

35 Kaufman SHE. In vitro analysis of the cellular mechanisms involved in immunity to tuberculosis. Rev Infect Dis 1989;11:S448-54.

36 Rossi GA, Balbi B, Manca F. Tuberculous pleural effusions: evidence for selective presence of PPD-specific $T$ lymphocytes at site of inflammation in the early phase of the infection. Am Rev Respir Dis 1987;136:575-9. 